\title{
Therapeutic effects of auriculotherapy on anxiety syndromes among adolescents: A scoping review protocol
}

\author{
Efeitos terapêuticos da auriculoterapia nas síndromes de ansiedade entre adolescentes: Um \\ protocolo de revisão de escopo
}

Efectos terapéuticos de la auriculoterapia sobre los síndromes de ansiedad en adolescentes: Un protocolo de revisión del alcance

Received: 03/29/2021 | Reviewed: 04/12/2021 | Accept: 04/14/2021 | Published: 04/26/2021

Luciana Maria Mazon

ORCID: https://orcid.org/0000-0002-6380-2233 Instituto Federal de Educação, Ciência e Tecnologia de Santa Catarina, Brazil E-mail: luciana.mazon@ifsc.edu.br

Josiane Steil Siewert

ORCID: https://orcid.org/0000-0002-8952-2360 Instituto Federal de Educação, Ciência e Tecnologia de Santa Catarina, Brazil E-mail: josianes@ifsc.edu.br

Vanderleia Muller Duarte

ORCID: https://orcid.org/0000-0003-0252-2016 Instituto Federal de Educação, Ciência e Tecnologia de Santa Catarina, Brazil E-mail: vanderleia.duarte@ifsc.edu.br

Emanuela Fernandes

ORCID: https://orcid.org/0000-0003-1708-4696 Instituto Federal de Educação, Ciência e Tecnologia de Santa Catarina, Brazil E-mail: emanuela.f@aluno.ifsc.edu.br

Gustav Oscar Dumke

ORCID: https://orcid.org/0000-0001-5489-1484 Instituto Federal de Educação, Ciência e Tecnologia de Santa Catarina, Brazil E-mail: gustav.dumke@gmail.com

\begin{abstract}
Introduction: anxiety syndromes are amidst the most frequent among adolescents appearing to be in the first forms of psychopathology. Drug Therapy and psychotherapy are strongly used in anxiety treatment, however, other therapeutic strategies are also been used, such as auriculotherapy, which consists of activating reflex points in the ear in order to improve mental and physical health. Objectiv: to map available evidences about the therapeutics effects of auriculotherapy on anxiety syndromes among adolescents. Inclusion criteria: This review will consider studies that include adolescents (10 to 19 years old) diagnosed with anxiety of any nature defined by the Diagnostic and Statistical Manual of Mental Disorders (DSM V) and that have undergone auriculotherapy to treat these clinical conditions. Methods: A three-step search strategy will be used for this review. The databases to be searched include MEDLINE (PubMed), CINAHL, LILACS, Scielo/ BDENF, Scopus, Embase and Web of Science. Quantitative and qualitative studies will be considered. Only studies published in English, Spanish and Portuguese will be included, with no date limit. The extracted data will be presented in a diagram or tabulated in a way that aligns with the objective of this scoping review. A narrative summary will also be presented.
\end{abstract}

Keywords: Adolescent; Anxiety; Treatment; Auriculotherapy.

\section{Resumo}

Introdução: os transtornos de ansiedade figuram entre os mais frequentes entre adolescentes e parecem estar entre as primeiras formas de psicopatologia. A terapia medicamentosa e a psicoterapia são fortemente empregadas no tratamento da ansiedade, no entanto, outras estratégias terapêuticas tem sido utilizadas, como a aurículoterapia que consiste na ativação de pontos reflexos no pavilhão auricular com o intuito de melhorar a saúde física e mental. Objetivo: mapear as evidências disponíveis sobre os efeitos terapêuticos da auriculoterapia nas síndromes de ansiedade entre adolescentes. Critérios de inclusão: Esta revisão considerará estudos que incluem adolesentes (10 a 19 anos) com diagnóstico de ansiedade de qualquer natureza definidos pelo Diagnóstico de Saúde Mental (DSM V) e que tenham sido submetidos a aurículoterapia para tratamento destas condições clínicas. Métodos: Uma estratégia de busca em três etapas será utilizada para esta revisão. Os bancos de dados a serem pesquisados incluem MEDLINE (PubMed), CINAHL, LILACS, Scielo/ BDENF, Scopus, Embase, Web of Sciense e Biblioteca Digital em Rede de Teses e Dissertações. Serão considerados estudos quantitativos e qualitativos, teses, textos e artigos de opinião. 
Apenas estudos publicados em inglês, espanhol e português serão incluídos, sem limite de data. Os dados extraídos serão apresentados em forma de diagrama ou tabular de uma forma que alinha-se com o objetivo desta revisão de escopo e um resumo narrativo será fornecido.

Palavras-chave: Adolescente; Ansiedade; Tratamento; Auriculoterapia.

\section{Resumen}

Introducción: os transtornos de ansiedade figuram entre os mais frequentes entre adolescentes y parecem estar entre as primeiras formas de psicopatologia. A terapia medicamentosa e a psicoterapia são fortemente empregadas no tratamento da ansiedade, no entanto, outras estratégias terapêuticas tem sido utilizado, como a aurículoterapia que consiste en ativação de pontos reflexos no pavilhão auricular com o intuito de melhorar a saúde física e mental. Objetivo: mapear as evidências disponíveis sobre os efeitos terapêuticos da auriculoterapia nas síndromes de ansiedade entre adolescentes. Critérios de inclusión: Esta revisión considerará estudos que incluem adolesentes (10 a 19 anos) con diagnóstico de ansieda de qualquer natureza definido pelo Diagnóstico de Saúde Mental (DSM V) e que tenham sido submetidos a aurículoterapia para tratamento destas condições clínicas. Métodos: Uma estratégia de busca em três etapa será utilizada para esta revisión. Los bancos de datos a serem pesquisados incluyen MEDLINE (PubMed), CINAHL, LILACS, Scielo / BDENF, Scopus, Embase, Web of Sciense e Biblioteca Digital em Rede de Teses e Dissertações. Serão revisados estudos cuantitativos e qualitativos, teses, textos e artigos de opinião. Apenas estudos publicados en inglés, espanhol e português serão incluídos, sem limite de data. Os dados extraídos serão apresentados em forma de diagrama ou tabular de uma forma que alinha-se com o objetivo desta revisão de escopo e um resumo narrativo será fornecido.

Palabras clave: Adolescente; Ansiedad; Tratamiento; Auriculoterapia.

\section{Introduction}

Adolescence is considered a risk phase for the development of anxiety syndromes and symptoms, ranging from mild transient symptoms to severe disorders (Beesdo, Knappe \& Pine, 2009).

Anxiety refers to the brain's response to danger, a stimulus that the body will actively try to avoid (Beesdo, Knappe \& Pine, 2009). According to the Diagnostic and Statistical Manual of Mental Disorders (DSM V), anxiety includes disorders that share characteristics of excessive fear and anxiety (American Psychiatric Association [APA], 2013)

There is evidence that anxiety disorders are amidst the most frequent among adolescents appearing to be in the first forms of psychopathology, increasing the risk of secondary anxiety and mood disorders (Wehry et al., 2015).

This condition has been identified among adolescents in several areas including educational environments. In Brazil, a report resulting from the International Student Assessment Program called "Student Welfare" published in 2016 by Organization for Economic Cooperation and Development reveals that Brazilian students are among the most stressed in the world and with higher levels of anxiety during exams. Approximately $80.8 \%$ of Brazilian students feel anxious during assessments and 56\% tense during the studies. The average of anxiety among students in the countries surveyed is 55.5\% (Organização para a Cooperação e Desenvolvimento Econômico [OCDE], 2016).

Another population-based study showed that among 1,621 adolescents interviewed, 20.9\% had some anxiety disorder and $8.6 \%$ risk of suicide (da Silva Rodrigues et al., 2012)

Several factors seem to contribute to this clinical condition among adolescents. The time that adolescents spend in front of the video-game screen was identified as a risk factor and was associated with severe anxiety (Maras et al., 2015). As well as the passive use of social media, that showed higher anxiety symptoms and depressed mood (Thorisdottir et al., 2019). Other studies suggest a relationship between this clinical condition and the physical inactivity noted among adolescents in the postmodern world (Tajik et al., 2017).

Drug Therapy and psychotherapy are strongly used in anxiety treatment (Schneider et al., 2018; Bennett et al., 2016). However, in recent years, other therapeutic strategies have been used, such as auriculotherapy. This technique is one of the Integrative and Complementary Care Practices recommended in Brazil by the Ministry of Health (Brasil, 2006; Brasil, 2017).

Auriculotherapy, also called ear acupuncture, consists of a Traditional Chinese Medicine modality that activates reflex 
points in the ear to improve physical and mental health (Mafetoni et al., 2018). The technique has been used in China since the Han dynasty, and was modernized in the following centuries (Zhao et al., 2015). The effects of this practice are explained by reflexology and neurophysiology.

The functionality of acupuncture occurs by stimulating reflex points in the sensitive fibers of the Peripheral Nervous System (Gori \& Firenzuoli, 2007). The auricular pavilion is considered a very important part of the human body because it constitutes a microsystem and can reflect all the pathophysiological changes of the organs and viscera, of the limbs, torso, tissues and sense organs. When stimulating certain points in this structure, areas of the brain are stimulated as well, discharging endorphins that acting systemically, will trigger the release of a neurotransmitter (Suen, Wong \& Leung, 2001).

Mind-body integration practices, such as auriculotherapy, have been increasingly popular in Western countries in the treatment of stress and anxiety disorders complementary to other treatments (Prado, Kurebayashi \& Silva, 2012; Breedvelt et al., 2019).

Primary studies evaluating the therapeutic effects of auriculotherapy in anxiety situations among adolescents have been published, however, there was no mapping of the results achieved in scoping reviews, with this therapy and in this age group.

A preliminary search was performed in the databases Open Science Projects, PubMed e JBI, no current scoping review was found on the subject.

Considering that the management of anxiety among adolescents is complex, knowing the effects of auriculotherapy on anxiety can strengthen the use of this practice, as another alternative to treatment, with low cost to public health services, complementary to those commonly used.

\section{Review question}

What are the therapeutic effects of auriculotherapy on anxiety syndromes among adolescents?

\section{Inclusion criteria}

\subsection{Participants}

Participants in this review will be adolescents with ages between 10 to 19 years. This review will consider studies that include this age group, diagnosed with anxiety of any nature defined by the Diagnostic and Statistical Manual of Mental Disorders (DSM V) and who have undergone auriculotherapy to treat these clinical conditions.

\subsection{Concept}

This review will consider studies that explore o the concept of adolescent defined by the World Health Organization was adopted, which includes individuals aged between 10 and 19 years (World Health Organization [WHO], 1986).

For the clinical condition of anxiety will be included cases associated with Panic Disorder, Specific Phobia, Social Phobia, Post-Traumatic Stress Disorder, Obsessive-Compulsive Disorder and Generalized Anxiety Disorder, according to the Diagnostic and Statistical Manual of Mental Disorders (DSM V) (American Psychiatric Association [APA], 2013).

The concept of auriculotherapy adopted, will be that of therapeutic technique that promotes the psychic-organic regulation of the individual through the stimulation of several points in the external ear (Brasil, 2017). Any auriculotherapy technique will be included, like, stimuli by seeds, acupuncture needles (facial or systemic) magnetic pellets, semi-permanent needles, electrophototherapy (laser or transcutaneous electrical nerve stimulation etc.) and / or protocol of any of the French lines (Paul Nogier) and / or Chinese (Traditional Chinese Medicine -MTC) (Yang et al, 2017). 
Studies with isolated auriculotherapy treatments or in association with another non-pharmacological intervention/therapy will be included, applied at different levels of health care, such as basic, specialized and hospital, conducted by a therapist trained in auriculotherapy.

\subsection{Context}

This scoping review will consider studies completed in all health care settings. Literature will be included from all countries or sociocultural settings.

\subsection{Types of sources}

This scoping review will consider experimental and quasi-experimental study designs, including randomized controlled, non-randomized controlled, before and after studies and time series studies. Analytical, prospective and retrospective cohort, case-control and cross-sectional observational studies will also be included. This review will also consider descriptive observational study designs, including case series and individual case reports and qualitative research.

\section{Methodology}

The proposed scoping review will be conducted in accordance with the Joanna Briggs Institute (JBI) (Aromataris \& Munn, 2020) methodology for scoping reviews. The protocol was registered with the OSF (Doi 10.17605/OSF.IO/NGZUT)

\subsection{Search strategy}

The search strategy will aim to locate both published primary studies.

A three-step search strategy will be used. Initially a limited initial search will be conducted on PubMed, followed by the analysis of the words of the text contained in the title and in the abstract, and of the descriptors used to describe the article.

Subsequently, a complete secondary search will be performed on all included databases, using the keywords and index terms identified in the initial limited search. The full search strategy for PubMed and Open Science Projects are included in Table 1. 
Table 1. Search strategy for PubMed and Open Science Projects, September 2020.

\begin{tabular}{|c|c|c|}
\hline \multicolumn{3}{|c|}{ Search Strategy for PubMed } \\
\hline Search & Question & $\begin{array}{l}\text { Recovered } \\
\text { records }\end{array}$ \\
\hline$\# 1$ & $\begin{array}{l}\text { (Auriculotherapy) OR (Auriculotherapies) OR (acupressure, Ear) OR } \\
\text { (Acupuncture, Ear) OR (Acupunctures, Ear) OR (Ear Acupunctures) } \\
\text { OR (Auricular Acupuncture) OR (Ear Acupuncture) OR } \\
\text { (Acupuncture, Auricular) OR (Acupunctures, Auricular) OR } \\
\text { (Auricular Acupunctures) }\end{array}$ & \\
\hline$\# 2$ & $\begin{array}{l}\text { (Adolescent) OR (Adolescents) OR (Adolescence) OR (Teens) OR } \\
\text { (Teen) OR (Teenagers) OR (Teenager) OR (Youth) OR (Youths) OR } \\
\text { (Adolescents, Female) OR (Adolescent, Female) OR } \\
\text { (Female Adolescent) OR (Female Adolescents) OR (Adolescents, } \\
\text { Male) OR (Adolescent, Male) OR (Male Adolescent) OR (Male } \\
\text { Adolescents) }\end{array}$ & \\
\hline$\# \mathbf{3}$ & Search ((\#1 AND \#2) & 202 \\
\hline \multicolumn{3}{|c|}{ Search strategy for Open Science Projects (OSP) } \\
\hline & $\begin{array}{l}\text { acupressure, Ear AND scope review } \\
\text { scope review AND acupressure, Ear } \\
\text { acupuncture, Ear AND scope review } \\
\text { scope review AND acupuncture, Ear } \\
\text { ear acupuncture AND scope review } \\
\text { scope review AND ear acupuncture } \\
\text { auricular acupuncture AND scope review } \\
\text { scope review AND auricular acupuncture } \\
\text { acupuncture, auricular AND scope review } \\
\text { scope review AND acupuncture, auricular }\end{array}$ & $\begin{array}{l}80 \\
04 \\
80 \\
105 \\
07 \\
32 \\
07 \\
08 \\
07 \\
105\end{array}$ \\
\hline
\end{tabular}

Fonte: Autores.

To help identify any additional studies, a tertiary literature search will be conducted by examining reference lists from all literature that meets the inclusion criteria for this review. If applicable, the reviewers intend to contact the study authors for more information.

Sources published in English, Spanish and Portuguese will be included. There will be no date limitation on the search strategy. The databases to be searched include: PubMed, CINAHL, LILACS, Scielo, BDENF, Scopus, Embase, Web of Sciense.

\subsection{Study/Source of evidence selection}

The selection of studies will take place in two stages, described below:

After the search, all identified citations will be grouped and uploaded to EndNote Web (Clarivate Analytics, PA, EUA) and the duplicates removed. To manage the selection process, Rayyan will be used (Mourad, Hossam, Zbys \& Ahmed, 2016). Titles and abstracts will then be selected by two independent reviewers for evaluation according to the inclusion criteria for the scoping review. Disagreements will be resolved by consensus meeting between the two reviewers.

The full text will be evaluated in detail by two independent reviewers. The reasons for excluding complete studies that do not meet the inclusion criteria will be recorded and reported in the scoping review. Any disagreements that arise between reviewers at each stage of the study selection process will be resolved through discussion or with a third reviewer.

The flow chart will follow the extension of the Check list for Systematic Reviews and Meta-analyzes for Scoping Review (PRISMA - ScR Check list) (Tricco et al., 2018). 


\subsection{Data extraction}

Data will be extracted from papers included in the scoping review by two independent reviewers using a data extraction tool developed by the reviewers. The data extracted will include specific details about the population, methods and Key findings, relevant to the review question.

\subsection{A draft extraction tool is provided}

The draft data extraction tool will be modified and revised as necessary during the process of extracting data from each included paper. Modifications will be detailed in the full scoping review. Any disagreements that arise between the reviewers will be resolved through discussion or with a third reviewer. Authors of papers will be contacted to request missing or additional data, where required.

\subsection{Data analysis and presentation}

The extracted data will be presented in diagram or table form in order to meet the objective of this scoping review.

The tables and mappings will inform about the auriculotherapy protocol used, type of anxiety and results of the auriculotherapy technique in the treatment of this clinical condition. A narrative summary will accompany the tabulated and mapped results and describe how the results relate to the purpose and issue of the review.

\section{Acknowledgments}

We thank Instituto Federal de Educação, Ciência e Tecnologia de Santa Catarina for the financial assistance.

\section{References}

American Psychiatric Association (2013). Diagnostic and Statistical Manual of Mental Disorders, Fifth Edition (DSM-V). Arlington, V. A.: American Psychiatric Association.

Aromataris, E., \& Munn, Z. (2020) JBI manual for evidence synthesis. Adelaide: JBI; 2020. Available fromhttps://synthesismanual.jbi.global.

Beesdo, K., Knappe, S., \& Pine, D. S. (2009). Anxiety and Anxiety Disorders in Children and Adolescents: Developmental Issues and Implications for DSMV. The Psychiatric clinics of North America, 32(3), 483-524.

Bennett, K., et al. (2016). Treating child and adolescent anxiety effectively: Overview of systematic reviews. Clin Psychol Rev, 50, 80-94.

Brasil. Ministério da Saúde (2006). Portaria no 971, de 03 de maio de 2006. Aprova a Política Nacional de Práticas Integrativas e Complementares (PNPIC) no Sistema Único de Saúde. Diário Oficial da União.

Brasil. Ministério da Saúde (2017). Portaria nº 849, de 27 de março de 2017. Inclui a Arteterapia, Ayurveda, Biodança, Dança Circular, Meditação, Musicoterapia, Naturopatia, Osteopatia, Quiropraxia, Reflexoterapia, Reiki, Shantala, Terapia Comunitária Integrativa e Yoga à Política Nacional de Práticas Integrativas e Complementares. Diário Oficial da União.

Breedvelt, J. J. F., et al. (2019). The Effects of Meditation, Yoga, and Mindfulness on Depression, Anxiety, and Stress in Tertiary Education Students: A MetaAnalysis. Front Psychiatry, 10:193.

da Silva Rodrigues, M. E, et al. (2012) Risco de suicídio em jovens com transtornos de ansiedade: estudo de base populacional Psico-USF, 17(1), 53-62.

Gori, L. \& Firenzuoli, F. (2007). Ear acupuncture in European traditional medicine. Evid Based Complement Alternat Med, 4 (1), 13-6.

Mafetoni, R. R., Rodrigues, M. H., Jacob, L. M. S., \& Shimo, A. K. K. (2018). Effectiveness of auriculotherapy on anxiety during labor: a randomized clinical trial. Rev. Latino-Am. Enfermagem, 26, e3030.

Maras, D., et al. Screen time is associated with depression and anxiety in Canadian youth (2015). Prev Med, 73, 133-138.

Mourad, O., Hossam, H., Zbys, F. \& Ahmed, E. (2016). Rayyan — a web and mobile app for systematic reviews. Systematic Reviews, 5, 21.

Organização para a Cooperação e Desenvolvimento Econômico (2016). Brasil no PISA 2015. Fundação Santillana.

Prado, J. M. Kurebayashi, L. F. S., \& Silva, M. J. P. (2012). Eficácia da auriculoterapia na redução de ansiedade em estudantes de enfermagem. Rev. esc. Enferm, 46(5), 1200-1206. 
Research, Society and Development, v. 10, n. 5, e4210514421, 2021

(CC BY 4.0) | ISSN 2525-3409 | DOI: http://dx.doi.org/10.33448/rsd-v10i5.14421

Schneider, S.C, et al. (2018). Multimodal Residential Treatment for Adolescent Anxiety: Outcome and Associations with Pre-treatment Variables. Child Psychiatry Hum Dev, 49(3), 434-442.

Suen, L. K. P., Wong, T. K. S., \& Leung, A. W. N. (2001). Is there a place for auricular therapy in the realm of nursing? Complement Ther Nurs Midwifery, 7(3),132-9.

Tajik, E., Abd, L., Adznam, S. N., Awang, H., Yit Siew, C. \& Abu Bakar, A. S. (2017). A study on level of physical activity, depression, anxiety and stress symptoms among adolescents. J Sports Med Phys Fitness, 57(10), 1382-1387.

Thorisdottir, I. E., Sigurvinsdottir, R., Asgeirsdottir, B. B., Allegrante, J. P. \& Sigfusdottir, I. D (2019). Active and Passive Social Media Use and Symptoms of Anxiety and Depressed Mood Among Icelandic Adolescents. Cyberpsychol Behav Soc Netw, 22(8), 535-542.

Tricco, A. C., et al. (2018). PRISMA extension for scoping reviews (PRISMA-ScR): checklist and explanation. The PRISMA-ScR Statement. Ann Intern Med, 169(7), 467-73.

Wehry, A. M., Beesdo-Baum, K., Hennelly, M. M., Connolly, S. D. \& Strawn, J. R. (2015). Assessment and treatment of anxiety disorders in children and adolescents. Curr Psychiatry Rep, 17(7), 52.

World Health Organization (1986). Young People's Health - a Challenge for Society. Report of a WHO Study Group on Young People and Health for All. Technical Report Series 731. WHO.

Yang, L. H., et al. (2017) Efficacy of auricular acupressure for chronic low back pain: a systematic review and meta-analysis of randomized controlled trials. Evid Based Complement Alternat Med, 2017: 6383649.

Zhao, H. J., Tan, J. Y., Wang, T., \& Jin, L. (2015) Auricular therapy for chronic pain management in adults: A synthesis of evidence. Complement Ther Clin Pract, 21(2), 68-78. 